\title{
Aleppo I: Double Rule of Law
}

\author{
Jan-Erik Lane \\ Institute of Public Policy, Belgrade, Serbia \\ Email: janeklane@googlemail.com
}

How to cite this paper: Lane, J.-E. (2016).

Aleppo I: Double Rule of Law. Open Journal of Political Science, 6, 393-412. http://dx.doi.org/10.4236/ojps.2016.64035

Received: August 11, 2016

Accepted: September 23, 2016

Published: September 26, 2016

Copyright (@) 2016 by author and Scientific Research Publishing Inc. This work is licensed under the Creative Commons Attribution International License (CC BY 4.0).

http://creativecommons.org/licenses/by/4.0/ (c) (†) Open Access

\begin{abstract}
Aleppo displays the two faces of the human race. On the one hand, it harbours an incredibly rich history of human civilisation dating back to the Sumer origins of organised society and government. On the other hand, it is today the victim of the worst atrocities human beings and states can commit, invoking religion, ethnicity and reasons of state. The destruction of Syria and its people is not based upon rational behaviour, because why would combatants keep fighting when there is no hope of an end on either side-no Zermelo point in the game? Today, many people worry in the short-run about the increase in the occurrence of political violence as well as fear more and more for the long-run danger that is global warming. A book with the title The End of History by F. Fukuyama (1992) appears completely misplaced, especially when "The Last Man" clause in this book cannot be ruled out from future projections for entirely different reason-climate change. The coming global consensus on democratic capitalism has been completely stuttered by events in the early 21st century: Koranic terrorism, the collapse of the Middle East, the provocations of North Korea, and the new brinkmanship of China in the South China Sea. Only one remedy to civil war and interstate confrontation exists. I wish to say, namely, double rule of law. This notion covers both domestic and foreign affairs, and it belongs more to the domain of normativity than rational choice or self-interest behaviour. Global rule of law is the only viable foundation for the mighty COP21 implementation process that now starts to prohibit that we arrive at the end of human societies.
\end{abstract}

\section{Keywords}

Rule of Law, Normativity, Civilisations, Justice, Liberal-Egalitarianism, Kant's Social Science, Public International Law, Well-Ordered Society

\section{Introduction}

As the 21st century has been labeled by biologists and physicists the "last" for the Cro 
Magnons, we could ponder upon a Kantian solution for mankind, so troubled and disturbed by comprehensive violence and vicious conflict. In his lesser known publications, where his peculiar metaphysics is absent-the foreign relations piece Perpetual Peace (1797) and the insightful analysis of domestic politics in Idea for a Universal History with a Cosmopolitan Intent (1784), I. Kant hit upon the greatest idea in the history of mankind, namely the rule of law (Kant, 1991). And he developed it for internal and external affairs in a way that was more relevant than ever today with globalisation and its terrible threat of global warming. These short pieces are eminently readable, lacking all the abstruseness of his theory of science and its untenable epistemology and ontology of the subjective nature of knowledge and the Universe. The possibility of subjectivist epistemology and ontology (das Ding an sich) like religious belief has been completely undone by the truly remarkable discoveries of the size (trillions of planets and stars) and inevitable end (dark energy) of the Universe, in the beginnings of the 21 st century. True knowledge is always objective, Popper (1934) argued convincingly in 1934.

The Uppsala genius Haegerstroem reminds us of Kant, as he also wrote abstrusely flawed philosophy of science, but launched brilliant insights into the subjective nature of values, launching his practical philosophy about human valuations, heavily influenced by Marxist insights about the social context of human interests (1953). Normative is always subjective. The values of the jihadists for which they kill innocents, women and children as well as their Shia kin are merely valuations. Haegerstroem would have argued correctly, their personal sacrifices will never be compensated due to their evilness by their God Allah. What really exists is only the set of religion founders: Zarathustra (probably), Moses (perhaps), Paul, Mohamed and Confucius. The man from Nazareth as well as the giant from Bodh Gaya may be inventions only. Religious belief is fairy tales, argued the greatest philosopher in the West, Baruch Spinoza-together with Paul the two most important Jews in human history.

Now, the governments of the states of world have decided upon the COP21 process of decarbonisation together with IGO:s and NGO:s. The objectives involved will require all the attention by governments, international organisations and ordinary people. This entails that domestic and international conflicts must be put at bay. It can only be done by endorsing double rule of law.

\section{Human Coordination: Rule of Law (RL)}

Kantian philosophy of the domestic Rechtsstaat and international Rule of Law provides now the ONLY basis for launching a credible and forceful response to climate change in international global governance, uniting the governments of the world against a major threat to life on the Planet Earth. Let us look at what rule of law-the most precious idea in political thought-entails for domestic affairs as well as for international affairs.

The co-ordination of governments and states would be facilitated if there were a common ground for interactions, like a coherent conception of justice. The liberalegalitarians have dominated the global justice discourse in academic for a few decades, 
trying to convince us that freedom and equality of outcomes can somehow be both achieved, if not maximised. However, the practical results are nil, as inequalities just grow and grow. A more realistic but very attractive global justice regime would be the globalisation of Kant's two rules of law regimes, one domestic and the other international. The liberal-egalitarian philosophy is a kind of democratic socialism or social democracy that suits only advanced capitalist countries, if at all. But rule of law trumps both democracy and socialism or social democracy. The ideas of an internal Rechtsstaat and of an external rule of law model set for internal governance could constitute the basic global agreement from which states could develop climate change policies that work. The conflict between freedom and equality is only partially resolvable. And we must find a global regime that can be attractive to other civilisations than the Protestant-Catholic one. A global rule of law ideology seems all the more urgent with the growth of nationalism, the explosion of Koranic terrorism and the new brinkmanship by Russia and China, threatening war.

\section{a) Domestic Rule of Law and Its Enemies}

Rule of law is not the same as democracy. A country like Switzerland can practice plebiscite democracy with constant referenda, while Germany has none of that. Yet, rule of law is stronger protected in Germany today. Turkey has had democracy for some decades, but hardly rule of law. Singapore is not a democracy but harbours some elements of rule law. Russia has never known the rule of law regime during its entire 1000 years history. When democracy is married with rule of law, we speak of constitutional democracies. Kant despised democracy but hailed the rule of law. Rousseau took that opposite position. Koranic countries like former Communist ones as well as Buddhist nations do not respect the rule of law requirements, though both may flirt with democracy at times.

The rule of law approach to politics and the state was elaborated much earlier than democracy and its institutions and political theory. In the world of politics today, we have basically three sets for domestic political affairs:

- Strong rule of law countries: a few Common Law nations, some Civil Law countries;

- Weak rule of law countries: Asia except Israel and India, Latin America except Chile and Costa Rica, all of Africa besides South Africa;

- Hobbesian societies where "life is brutal, nasty, poor and short": Middle East, Turkestan, central and eastern Africa, the Caribbean. They are at a pre-rule of law stage.

Thus, the majority of states that signed the COP21 Agreement are not in respect of rule of law. How, then, can they be convinced to respect their signed obligations? The COP21 promises a super fund with enormous yearly transfers to Third World countries without mentioning the systematic corruption in several of these countries. It is as if asymmetric information and opportunistic behaviour never occurred to these global meetings and declaration, which are truly transaction cost heavy.

Rule of law is of such urgent importance, because the Western exigencies about democracy and capitalism will never be accepted by two major civilisations, namely the Koranic one and the Buddhist one. Together they are much larger than the Protes- 
tant-Catholic civilisation, especially when Islam covers both Sunnis and Shias as well as the Buddhist civilisation is correctly covering East Asia and South East Asia. The Orthodox civilisation, emerging from the Russian tragedy of Leninism-Stalinism, is definitely not worshiping rule of law. Yet, rule of law is globally relevant from the point of view of justice. And it is practically feasible also in Islam and Buddhism.

\section{b) Where Koranic Terrorism Comes From}

When searching for the roots of radical Islam, one cannot bypass Moslem thought in greater India under British rule-Deobandi school. Several scholars had a profound influence on Islam in Arabia, such as for instance Mawdudi, theorising not only islamisation but also Islamic finance before the Egyptians Qutb and Faraj. These tnree men staked a Koranic Revolution, changing the mind set of Sunnis. Without this ideaological reformation of Islam, no fundamentalist jihadism.

The message of radical Islamic fundamentalism (Mawdudi, Qutb, Faraj) conflicts not only with the main values in the other global civilisations. It also harbours conflicts within the Koranic civilisation, as the Sunni-Shia civil war, which can only lead to one thing: misery for not only religious or ethnic minorities in the Middle East but for all Moslems themselves, whether Sunnis or Shias.

This phrase- "religion of warriors" - is the overall characterization by sociology giant Max Weber of Islam in his comparative studies of religion and the modern economy in the early 20th century. However, the solution to the problem of accommodating Islam to modernity is not so much found in the resistance of Islam to the market economy-capitalism, which Weber theorised. The problem is not to be found in capitalism, as with Weber, but in the opposition between on the one hand a radical fundamentalist interpretation of Islam, with the new Salafists, and on the other hand the universal recognition of human rights as well as rule of law.

Radical Islamic fundamentalism has as its main objective to guard the borders of the Koranic civilisation to other religions. Thus, they fear proselytise or mission or conversion campaigns by other religions, the occurrence of apostasy among their own adherents as well as the emergence of schisms or dogmatic splits within their own ranks. All the world religions have reacted with violence against these three threats. Perhaps the posture of Islam is the least open or tolerant in these matters. In the Muslim civilisation marriage, for instance, entails that a woman adhering to another religion than Islam converts to the same religion as her husband. It is not difficult to find within the Koran very strong admonitions against proselytism, apostasy and schisms.

Global radical Islamic terrorism has a disastrous impact not only upon the countries targeted but also upon the Muslin countries themselves, setting in motion millions fleeing. As we have seen, Weber put the concept of jihad at the centre of Islam in his short historical analysis of the fate of this religion with the Prophet and after him. Several Muslim scholars would deny the correctness of Weber's theory of Islam as a religion of warriors, pointing to the fundamental fact that Islam has just five fundamental duties, which do not include jihad (Huff \& Schluchter, 1999; Robinson, 1999; Rodinson, 1993; Metcalf, 1999). 
The world religions have often in history been conducive to the occurrence of large scale political conflict. And all of them have developed some form or other of fundamentalism that are violent in the twentieth century (Juergensmeyer, 2000).

Yet, two things should be underlined when speaking about the concept of jihad in the Muslim civilisation: first, Jihad as a core element in Islam is a concept that was launched in the twentieth century; second, legitimate Jihad within Islamic fundamentalism presents mainly two different aspects: 1) violence against foreign intrusion into the Muslim civilisation; and 2) violence towards internal sources of secularisation within the Muslim societies.

The new or reinterpreted concept of jihad together with the ols notion of a caliphate, based upon the basic notion of "pagan ignorance" (jahiliyyah) constitute the core of the radical transformation of Islam in the 20th century by three men. They are of world importance (Abadie, 2004; Abu-Rabi', 1996; Ali, 2002; Al-Najjar Fatiha Dazi-Héni, 2006; Ashmawy, 1994; Ayubi, 2003; Azmeh, 1996; Babès \& Oubrou, 2002; Bachar, Bar, Machtiger, \& Minzili, 2006; Badawi, 1968; Badawi, 1972; Baderin, 2003; Badie, 1986).

\section{1) $M A W D U D I$}

Mawdudi, Abul "Ala" (1903-1979) was the greatest architect of the contemporary Islamic revival, considered by many to be the most outstanding Islamic thinker and writer of our time. Mawdudi was influenced by Hasan al-Banna and the Egyptian Muslim Brotherhood (MB). He founded the Jama'at-i-Islami movement in 1941 in the Indian sub-continent, an extremely well-organised association committed to the establishment of an Islamic world order that has played an important role in the politics of Pakistan, India, Bangladesh and other South-East Asian countries.

The Muslim community in India responded to the British destruction of the Mogul Empire in 1859 with a seminary in Deobandi in 1866 by former students of the Delhi madrassa, destroyed after the "Revolt of 1857". The new seminary in Deobandi aimed at 1) indoctrinating Muslim youth with Islamic values, and 2) cultivating intense hatred towards the British and all foreign (i.e. non-Islamic) influences. The seminary exposed their students only to the spiritual and philosophical traditions of Islam with the goal of islamisation of state and society in view (Rahbar, 1956).

However, the Aligarh movement would serve Moslems better than the Deobandi School. Aligarh became famous as a centre for various movements that shaped India with the start of the Mohammedan Anglo Oriental College by Sir Syed Ahmed Khan in 1875. This College became Aligarh Muslim University—a hub for bridging the gulf between Islamic and Western cultures. Mawdudi opposed to the secularist nationalist Muslim League led by Jinnah, but on change from being merely a state for Muslims to an Islamic state. His political involvement and criticism of government policies, as well as his anti-Ahmadiya agitation, led to his imprisonment in 1953, but the death sentence passed was never carried out. Mawdudi saw Islam as threatened by a wave of Westernisation.

This much venerated theologue and clericc today conceived of true Islam as a total comprehensive system and ideology, incorporating society, politics and the state-the 
caliphate idea. Mawdudi differentiated sharply between jahiliyyah, which included most contemporary Muslim societies and true Islam. His goal was an ideological Islamic state based on God's sovereignty (hakimiyya) and on Sharia. As an explanation for the decline of Muslim power, Mawdudi concluded that diversity was the culprit: the centuries old practice of interfaith mixing had weakened andnwatered down Muslim thought and practice in that region of India.

\section{2) $Q U T B$}

Radical Islamic societies (jama'at) emerged out of the Muslim Brotherhood founded 1928, drawing on the thought of its main ideologue, Sayyid Qutb, who endorsed a violent takeover of power. Qutb (2000) reinterpretation of several key Islamic concepts inspired some to split off from the Brotherhood and use his writings to legitimise violence against the regime. He argued that the existing society and government were not Muslim but rather dominated by "pagan ignorance" (jahiliyyah). The duty of righteous Muslims was to bring about God's sovereignty (hakimmiyya) over society, denounce the unbelief ( takfir) of the current national leaders, and carry out a holy struggle (jihad) against them, whether Arabs or not, Muslims or not, active or passive supporters of ignorance Sivan (1995).

Sayyid Qutb (1906-1966) was an Egyptian and as a member of the MuslimBrotherhood, a prominent Islamist figure whose career spanned the middle decades of the century. His thought, deeply influenced by Mawdudi's revolutionary radicalism, falls into two distinct periods: that which occurred before President Nasser detained him in a concentration camp for political enemies (he was eventually executedt. The first excerpt comes from an early work, Social Justice in Islam, which he wrote in 1949, translated by John B. Hardie (1970). Qutb builds on the old Sunni Islamic idea of tawheed (the singularity of God and, therefore, of the universe):

"So all creation issuing as it does from one absolute, universal, and active Will, forms an all-embracing unity in which each individual part is in harmonious order with the remainder ... Thus, then, all creation is a unity comprising different parts; it has a common origin, a common providence and purpose, because it was produced by a single, absolute, and comprehensive Will ... So the universe cannot be hostile to life, or to man; nor can "Nature" in our modern phrase be held to be antagonistic to man, opposed to him, or striving against him. Rather she is a friend whose purposes are one with those of life and of mankind. And the task of living beings is not to contend with Nature, for they have grown up in her bosom, and she and they together form a part of the single universe which proceeds from the single will."

With the crackdown on the Muslim Brotherhood following the 1954 assassination attempt on Nasser, Qutb was arrested and spent 10 years in prison. He was freed in 1964, but re-arrested in 1965, tortured and executed in 1966. While in prison he wrote his greatest work, an eight-volume tafsir of the Koran, Fi Zilal al-Quran. Towards the end of his imprisonment he wrote Milestones (Ma'alim fil-Tariq) - the key manifesto of 
radical Islamic groups, providing radical fundamentalism in Islam with its foundation and key propaganda pamphlet:

"The Islamic civilisation can take various forms in its material and organisational structure, but the principles and values on which it is based are eternal and unchangeable. These are: the worship of God alone, the foundation of human relationships on the belief in the Unity of God, the supremacy of the humanity of man over material things, the development of human values and the control of animalistic desires, respect for the family, the assumption of the vice regency of God on earth according to His guidance and instruction, and in all affairs of this vice-regency, the rule of God's law (Sharia) and the way of life prescribed by Him."

\section{3) FARAJ}

"Holy terror" is a term for "holy assassination" in the Middle East, applicable to the assassinations of Sadat and Rabin and what came after The assassins of Sadat were guided by Muhammad Abd al Salam Faraj (1954-1982) and his booklet, The Neglected Duty, to violent behaviour. Faraj arrived at this jihad (holy war) duty by considering and rejecting non-violent options: participation in benevolent societies; obedience to God, education, abundance of acts of devotion, and occupation with the quest of knowledge; exerting oneself in order to obtain an important position; and democratic options such as engaging in civil liberties such as freedom of speech, the founding of a political party to compete freely with other parties in elections, and the creation of a broad base of support resulting in majority rule. Faraj believed that none of these would lead to the messianic goal of establishing of an Islamic state and ultimately reintroducing the caliphate.

Thus, the main ideologue of jihad was Faraj, a former Muslim Brotherhood member, who was disillusioned by its passivity. But al-Jihad did not restrict itself to theory alone. It quickly became involved in sectarian conflicts and disturbances in Upper Egypt and Cairo. After the assassination of Sadat at a military parade, al-Jihad supporters fought a three-day revolt in Asyut, seeking to spark a revolution, before being defeated. In contrast to Takfir, al-Jihad was not led by one charismatic leader but by a collective leadership. It built up a sophisticated organisation run by a leadership apparatus in charge of overall strategy, as well as a 10-member consultation committee headed by Sheikh Umar'Abd al-Rahman. Faraj recruited for al-Jihad in private mosques in poor neighbourhoods where he delivered Friday sermons.

In contrast to the traditional religious scholars, who proclaimed the necessity of submission to any ruler claiming to be a Muslim, they insisted that acceptance of a government was only possible when the Islamic legal system is fully implemented. Implementation of Sharia becomes the criterion of the legitimacy of regimes. Traditional scholars viewed the concept of the "age of ignorance" or paganism (jahiliyyah) as an historic condition in pre-Islamic Arabia. However, "ignorance" (jahiliyyah) is a present condition of a society which is not properly Islamic because it does not implement the full Sharia and hence is rebelling against God's sovereignty. All the regimes currently in power in Muslim countries are thus not acceptably Islamic and it is both right and nec- 
essary to rebel against them.

Faraj argued that active, immediate jihad would be the only strategy for achieving an Islamic state. Instead of seeing Jews and Christians as protected communities (dhimmis) and "People of the Book", the two groups viewed them as infidels both because they had deliberately rejected the truth and because of their connections to colonialism and Zionism. They were accused of serving as a "fifth column" for external enemies; Takfir stressed an international Jewish conspiracy and the need to fight it, whilst al-Jihad viewed Christians as the first enemy to confront and was heavily involved in anti-Coptic activities. Consequently, Sheikh Abd al-Rahman issued a religious legal edict (fatwa) legitimising the killing and robbing of Christians who were said to be anti-Muslim. Both groups saw the Christian West, Jewish Zionism and atheist communism as planning to corrupt, divide and destroy Islam, the rulers in Muslim states being puppets of these forces, leading their countries into dependence and secularisation (Moaddel \& Talattof, 2000; Moghadem, 2007; Mussallam, 2005; Qureshi, 1980; Qutb, 1990; Qutb, 2005).

\section{c) Is Deobandi Theology Really Islam?}

How the ISIS group related to Al Qaeda in Iraq is not fully known. The key person was Abū Muș'ab az-Zarqāwī, who was a leader of the insurgence against the Allied invasion of Iraq. He was not only violently anti-Western but also a sworn enemy of Shiism. He was so bloody in his strategy and tactics-suicide and car bombs-that al-Zawahiri objected, leading to a split from Al Qaeda by az-Zarqāwì. After his death, his main ideas inspired the creation of ISIS. These are the basic ideas of the man called "AMZ":

"i. Remove the aggressor from Iraq. ii. Affirm tawhid, oneness of God among Muslims. iii. Propagate the message that "there is no god but God", to all the countries in which Islam is absent. iv. Wage jihad to liberate Muslim territories from infidels and apostates. v. Fight the taghut ruling Muslim lands. vi. "Establish a wise Caliphate" in which the Sharia rules supreme as it did during the time of Prophet Mohammad. vii. "Spread monotheism on earth,cleanse it of polytheism, to govern according to the laws of God..." (Hashim, 2014).

When Al Qaeda asked AMZ not to target ordinary Moslems, especially Shias, the reply was in the style of future ISIS (Hashim, 2014):

"We did not initiate fighting with them, nor did we point our slings at them. It was they who started liquidating the cadres of the Sunni people, rendering them homeless, and usurping their mosques and houses."

Thus, AMZ or az-Zarqāwi is much more to be seen as the forerunner of ISIS than al-Zawahiri. But his ideology or religion is the radical Islamic fundamentalism, created by the three: Mawdudi, Qutb and Faraj (Burgat, 2008; Choudhury, 2003; Corbin, 2002).

Al-Zawahiri (1991) wrote several books on Islamic movements, the best known of which is Knights under the prophet's banner (2001), which outlines the new strategy of Sunni fundamentalism. He refers to Qutb to justify murder and terrorism, but also to 
Pakistani Jamaat-i-Islami founder and scholar Mawdudi on the global mission of jihad. Osama Bin Laden had the money, some connections and perhaps the charisma to function as the leader of the al-Qaeda global jihad, but when Zawahiri's al-Jihad 1998 joined forces with Bin Laden, the global Islamist terrorist threat emerged. Now, the ISIS employs the ruthless tactics of AMZ or az-Zarqāwī, killed in Iraq.

As fundamentalism with this new doctrine of Islamic terrorism becomes more wide spread in not only the Muslim civilisatin but also Europe, North America and Africa in the early twenty-first century (Roy, 1994, 2000, 2004, 2007, 2008; Kepel, 2000, 2004, 2005, 2008), Weber's classic perspective-Islam as a religion of warriors-is more relevant than it was hundred years ago (Weber, 1978; Crone, 1999). It is more vindicated by the new Salafists than he ever imagined himself. His concept of Islam as a religion of warriors is verified with a terrible vengeance by the combination of salafism and jihad in the new Islam of the gang of three (Metcalf, 1982; Metcalf, 1999; Huff \& Schluchter, 1999; Miller \& Kenedi, 2002; Milton-Edwards \& Hinchcliffe, 2001).

The new theory of jihad entails, according to Maududi:

"Islam is a revolutionary doctrine and system that overturns governments. It seeks to overturn the whole universal social order ... and establish its structure a new ... Islam seeks the world. It is not satisfied by a piece of land but demands the whole universe ... Islamic Jihad is at the same time offensive and defensive ... The Islamic party does not hesitate to utilize the means of war to implement its goal."

The religious community of Moslems (umma) has always been heterogeneous and the fusion of secular and religious power hzr proved non-viable for Muslim countries (caliphate, immmate). A Muslim state can only be stable and prosperous, if these two fundamental facts are acknowledged by all religious groups, the ulema or muftis. The Islamic civilisation must accept the secular nature of a modern state, where the respect for Rule of law would stop the infernal civil wars in the Muslim civilisation. And only the majority Sunnis can reject the dire Deobandi teachings in various institutions: mosques, madrasas, universities, schools and in Western communities, which would stop the supply of "martyrs" (Schluchter, 1987; Schluchter, 1989; Sivan, 1985, 1997; Baderin, 2003). The gang of three has most severely heightened the tension between Sunnis ans Shias, of course regarding Shiism as flawed version of the message of the prophet, to be ultimately out routed.

\section{Global Rule of Law}

It is an undeniable fact that foreign affairs have become more regulated than ever before-normativity, speaking generally about the global market and the interactions among states, international as well as regional organisations like the EU and ASEAN. However, how this seemingly inexorable march towards normativity to be theorized in relation to the classical paradigms: realism versus idealism or liberalism? On the one hand, a new realist interpretation has been launched by Eric Posner (Goldsmith \& Posner, 1995). On the other hand, the new cosmopolitanism envisages foreign affairs on 
the model of domestic affairs in so-called well-ordered countries.

The international system is no longer in a state of anarchy where the principle of self-help applies. Not only have the IGOs grown more influential than ever before, but there has also emerged a global community comprising energetic NGOs. Key principles in public international law, viz state sovereignty and self-help, now has to co-exist with other principles, such as e.g. humanitarian intervention, national self-determination and human development. Numerous central features of the anarchy system have been transformed, resulting in a slow but unstoppable growth in normativity.

\section{Rule of Law in Global Governance}

The call for normative in relation to the international system, modeled as anarchy and self-help, has a more solid foundation than idealist blue-prints for an international community in eternal peace, as with Kantian ism for instance. It starts from the body of principles laid down in public international law (PIL), comprising not only treatises but also custom and self-evident reasons. PIL has existed for centuries, constituting the set of norms guiding diplomacy. After the Second World War, PIL has been codified in numerous standard textbooks of ever increasing size.

Controversy has much dominated the theorizing on PIL, linking up this debate on the nature of PIL with the opposition between idealists and realists. PIL would be:

1) Morality and not law;

2) Recommendations that are not self-enforceable;

3) Norms without enforcement;

4) Pacifist notions that are unrealistic;

5) Global regulation that would be biased or dangerous.

One finds reminiscences of these antimonies in the now surging debate on PIL, as it has evolved after the Great War (Besson \& Tasioaulas, 2010; Dunoff \& Trachtman, 2009; Klabbers, Peters, \& Ulfstein, 2011; Posner, 2009).

\section{International Rule of Law = Convenient Recommendations?}

The rebuttal of normativity with PIL from Goldsmith and Posner is entirely different from naive geopolitics. They present a most elaborate theory of PIL, combining jurisprudence with international relations, interpreted with a few basic game theory models.

Posner (2009) is highly sceptical about Voelkerrecht, its foundations and its claim to normativity, meaning that its key principles bind sovereign states. However, Goldsmith and Posner do not reiterate Schmitt's position from 1928 towards PIL (Schmitt, 2002). They confirm that PIL is LAW, and not merely the morals of victorious governments. Yet, they completely deny normativity. How could a system of norms that constitute LAW lack entirely normativity?

According to this theory of PIL, PIL is often complied with but not because of any binding force of its norms. Compliance can be best explained by the operation of state interests and their coordination in the games that are played out underneath PIL. Moreover, governments have no obligation whatsoever to comply with PIL. Thus, the enforcement is entirely up to the states in the international system that may or may not comply alternative may or may not retaliate against reneging by other governments, all 
based upon consideration of self-interests.

Posner's rejection of any obligation with PIL may appear drastic, but it may be related to the perennial debate about what is law. Law, all agree, is a huge ordered set of couples of norms and their enforcement:

Law $=\langle$ norms, enforcements $>$.

What is contested is whether the binding nature (validity) of the first elementnorms-is the same or different from the efficacious nature of the second elementcompliance or punishment. Kelsen's legal positivism took the view that law's validity is conditioned by its effective enforcement, whereas Swedish philosopher Axel Haegerstroem developed the legal realist approach that legitimacy of norms is nothing but the same as their probability of compliance (Eliasson, Mindus, \& Turner, 2012). Normativity and legal validity is never objective in the sense of the objective exstenc of the Universe (Raz, 2009) Legal pragmatists like for instance Richard Posner (1993) shares the Haegerstroem view: "law is a prediction about what the judges will do". Since states sometimes comply with and sometimes renege with PIL on the basis of self-interests, Posner draws the conclusion that PIL has no normativity or binding validity, neither Treaty Law ("pacta sunt servanda") or Customary Law ("opinio juris").

It is true that PIL differs from domestic law as far as the probability of compliance or enforcement is concerned, at least in well-ordered countries. But this was always the standard objection towards PIL. And how can it lead so far that it is claimed that it has no binding force whatsoever, at the same time as the probability of enforcement is increasing? PIL may be deficient as LAW, but how can it be LAW and have no normativity?

PIL is grounded only upon state interests, guiding them to various forms of coordination at best, as well as to renege at worst. States would have behaved in the same way without treaties or customary international law, in accordance with various equilibria in non-cooperative game theory. This position bypasses entirely the transaction cost saving nature of LAW. States could not handle all the transaction costs from solving a myriad of alternative interaction games, day in and day out. Better to rely upon the binding nature of valid norms with a general scope, guiding action in similar circumstances.

One may wish to contrast the new realist argument by Posner with the new cosmopolitanism, which dreams of a development of PIL towards morals and natural law, i.e. more of legitimacy but little or none of efficacy (Manners, 2002).

\section{Global Rule of law = Radical Cosmopolitanism?}

Has PIL and its normativity evolved so much recently that it can be considered as a global rule of law regime, comparable to the Rechtsstaat within a country. Teitel's argument consists of three parts theorizing what she calls humanity's law (Teitel, 2011):

a) Humanity's law comprises essentially the following parts of the PIL: the Geneva and

Hague conventions about the conduct of inter-state war: just war as well as justice in war, the Treaty of ICC (International Criminal Court) and the Security Council decisions concerning the ad hoc courts for Former Yugoslavia and Rwanda: personal 
security in intra-state civil war and anarchy;

b) Humanity's law offers person protection in several ways similar to rule of law regimes within a country;

c) Humanity's law has a structure similar to that of domestic rule of law.

I would not hesitate to suggest that the suggested strong linking of the PIL with cosmopolitan moralism would weaken the emerging normativity in international relations. What Teitel calls "humanity's law" is hardly comparable to rule of law in so-called wellordered societies.

Firstly, the Geneva Conventions are hardly new, as they began to be laid down around 1900. Second, together with the Hague Conventions they offer a number of norms about the conduct of war and use of violence in conflicts, but these norms have had almost nil impact upon reality. Whereas the so-called efficiency of rule of law tends to be high in the capitalist democracies or well-ordered countries, the opposite is true of humanity's law. In addition, the ICC has not met with universal acceptance and the capacity of the ad hoc tribunals to punish perpetrators has been rather meager. Thus, also with regard to legitimacy the framework of humanity's law is hardly to be compared with the rule of law regime when solidly implemented as within the OECD countries. Thirdly, whereas Humanity's law targets the protection of civilians against physical violence from either interstate or intrastate conflicts, the rule of law regime has a much broader scope than merely the Habeas Corpus rights. Thus, rule of law today entails constitutionalism, which is lacking in Humanity's law.

Rule of law only exists when there is a high probability that its norms are complied with, either directly or indirectly through enforcement against deviations from observing these rules. Teitel speaks of humanity's law "providing protection", "offering protection" etc. But the respect for these norms is often so low that this is only a manner of talking about LAW.

When theorizing globalization, cosmopolitanism and law, one cannot bypass the insights from the philosophy of law, distinguishing between norms on the one hand (validity) and their implementation on the other hand (efficacy). Just because the new cosmopolitanism speaks much about universal rights, it does not turn these moral rights into substantive law.

The new theory of cosmopolitanism, launched by so-called liberal egalitarians, purports to be a global political theory for the globalisation age. It is based upon various theories of justice in recent political philosophy, resulting in Utopian conclusions. A key text is that of Caney (2006), who presents the following ethical principles or recommendations:

- People in Kuwait are not entitled to its oil reserves;

- People should be taxed for using the resources in their territory, and the proceeds spent on improving the poor throughout the world;

- There should be a system of multi-level government in which the power is removed from states to both supra-state and sub-state authorities.

New cosmopolitanism is much broader than old cosmopolitanism according to the 
Kantian framework. Whereas the latter concentrated upon peace and the regulation of violent conflicts, new cosmopolitanism underlines global distributive justice besides launching civil and political rights. It goes far beyond public international law. Are we then to say that it gives directions for the future improvements of the law of the international community- "Voelkerrecht"? I much doubt that, as the new cosmopolitanism with for instance the three proposals above is Utopian, whereas the PIL framework is practical.

The call for global democracy is a cornerstone in the new cosmopolitanism (Held, 1995). Scholars calling for more of democracy envisage either small reforms of global institutions in an egalitarian direction or they suggest that pressure should be exercised upon countries that are illiberal. PIL endorses state sovereignty together with non-interference on the one hand as well as human rights as well as humanitarian intervention on the other hand. Thus, PIL as a whole is hardly a consistent normative framework. But it holds true that in any case PIL does not entail global democracy, which call today would amount to a culture blind "exigency" (Rawls, 2001).

\section{International Rule of Law $=$ Spontaneous Order}

The augmentation of normativity along with the process of globalisation has led to a debate about the pros and cons of global constitutionalism (Krisch, 2011; Dobner \& Loughlin, 2012). One should separate between the expansion of PIL on the hand and various efforts at regional or global constitutionalism. As the failure of EU constitutionalism shows, constitutions make much sense at the level of nation-states. Globally, the PIL framework advances slowly but inexorably by means of the principle of "muddling through". The PIL is not planned or designed as a whole set of rules. Instead it has expanded in scope and range in an incremental fashion. It builds upon the accumulated wisdom of a variety of efforts over a few centuries to codify a set of reasonable rules for the interaction of states as well as the protection of persons (Young, 1989; Keohane, 2005; Krasner, 1983, 1999).

\section{Objective and Subjective Validity}

In the philosophy of right and legal theory, it is emphasized that ethics and justice have to do with rules, whether the approach is a deontological or one of consequentiality. Legal norms fulfill this requirement of generalisability of universalisability, inherent in morality (Hare, 1972). In various domains of activity-economics, environment, state interactions, humanitarian efforts, there has occurred a seminal trend towards normativity since 1945 and especially 1990. It blurs the traditional separation between realism and idealism that has dominated IR. The inexorable drive towards more of normativity has accompanied the major changes in the international system or foreign relations:

- The strengthening of the IGOs (Pogge, 2002);

- The creation of regional organizations;

- The evolution of a global civil society: NGOs and CSOs;

- The creation of new global courts, ad hoc or permanent besides the ICJ;

- The expansion of domestic courts into international affairs. 
However, growing normativity or the institutionalisation of rule of law does neither entail global constitutionalism, nor even that the basic problem of public international law-implementation or enforcement-has been resolved adequately. Idealism, especially in the form of Utopian cosmopolitanism remains unrealistic, but realism has been tempered by normativity and must be so increasingly in the 21 st century. If rule of law entails justice for mankind, domestically and in foreign affairs, then maybe social justice implies real equality, or a new form of socialism?

\section{Irrelevance of Socialism}

"What is wrong with socialism?" ask Barry rhetorically, quoting Harold Pinter. Barry, launching the idea that justice is impartiality as well as that impartiality is equality, intends the question as rhetorical device for replying NOTHING. There are in fact many errors with socialism that explains its failure, from Owen's village in the 19th century to Cuba and Venezuela over the disastrous Soviet experiment. Thus, one can claim evidence to the effect that a socialist economy:

- does not make people happy;

- cannot produce much output;

- favours its leadership in reversed inequality;

- tends towards dictatorship sooner or later;

- it could not be introduced by means of a majoritarian referendum.

People have made so bad experiences from socialist projects and the behaviour of Communist parties that they prefer market capitalism, where they at least receive goods and a small salary, accepting with anger the incredible remunerations of CEO:s in capitalist enterprises-a huge market failure in fact. The principal-agent problematic of adequately rewarding CEO:s has not been resolved in modern economic and management theories, but it occurs to the same extent in public enterprises (one worst example: Swedish energy giant Vattenfall).

The liberal egalitarians dream about retaining liberty fully while increasing real equality, either ex ante as Dworkin $(1986,2000)$ or ex post as Rawls (1971). They refer to Social Democracy generally and Sweden in particular. But liberal-egalitarianism did not work out in Sweden. The CEO:s, privately or in public enterprises, take home enormous payments plus bonuses. And the number of scandals from corruption in both sectors has increased sharply. Academic professors, one well-paid, and sometimes supportive of the Arbeiterbewegung, are remunerated with the salaries of clerks in companies like Erickson, SHB and Elux. Bonuses and perquisites have skyrocketed after the death of Olof Palme. Prominent social democrats are sometimes active in capitalist endeavours, also together with public office.

Interestingly, the socialist economy and the maker economy suffer from one major common problematic, viz. the principal agent difficulties. While socialism fails completely to resolve it, opening up for the mismanagement typical of public enterprises and firm, capitalism struggles with it without success. That is why CEO:s who fail often demand even more remuneration. Only the shareholders can resolve the principalagent games, but they face coordination problems and collusion between the CEO:s and 
a few dominant owners on the company board.

Barry's proof of justice (Barry, 1995) as real equality is merely a huge circular argument:

1) Justice is impartiality (assumption in Law);

2) Impartiality is formal equality (assumption in Law);

3) Real equality is more reasonable than formal equality (assumption unproven);

4) Justice is real equality.

A thing or argument is reasonable when it cannot possibly be rejected. What, then cannot be reasonably rejected? Barry answers that income and wealth inequalities canreasonably_be rejected by the poor man or woman. No reward for effort, capacity, merit? No recognition of inheritance? Not reasonable because it implies partiality? Real equality is reasonable, and reasonable is impartiality, which is justice. QED. The Barry argument relying upon the ambiguous notion of reasonableness does not hold. As Weber emphasized, moral argument and ethics cannot rely purely upon reason-the so-called Hume's position. Practical syllogisms, if correct at all, must have at least one moral principle (OUGHT), the validity of which comes from emotion, will or decision, and not reason. Why is real equality of socialism more reasonable than liberty and the market economy?

The efficient and just socialist economy is a figment of imagination. Macro speaking, socialist planning replacing market capitalism sooner or later degenerates into oppression, like in the USSR, Yugoslavia, Hungary, Cuba and now Venezuela. The economic rise of East and South Asia started when the market economy was endorsed by government. Micro speaking, socialism is not incentive compatible, as its altruism is Utopian.

I have nothing against social democracy and its redistribution zest as long as it respects the market foundations of an efficient economy. The unresolved problem, however, is how much redistribution is $D U E$ to everyone.

\section{What is Justice?}

There has been an intensive discussion about social justice for some hundred years in the social sciences, jurisprudence and economic theory. Up to about the 1950s, the main approach was the non-cogntivist one with Weber (1978), Haegerstroem (1953) and Kelsen (1911), stating that social justice harbours ultimate valuations tht cannot be derived from reasonable ideas or principles. This so-called Humean principle that justice involves inextricably an element of feelings or will (non-cognition), has been completely pushed aside in political theory during the recent 50 years, with a number of cognitivist frameworks, like for instance Barry's (Barry, 2005). Not all cognitivists are liberal-egalitarians, as its main competitor, neo-liberalism, has also been rendered a cognitivist backing, at least sometimes.

The problem can be formulated thus: The great Roman lawyers identified the concept of justice as follows:

Juris praecepta sunt haec: honeste vivere, alterum non laedere, suum cuique tribuere, translated as: Such are the [basic] principles of the Law: live honestly, do not offend 
others, give to each person what is due. Corpus Juris Civilis, Pandects.

It contains an eliptic phrase: "suum cuique tribuere", give each man his or each woman her due. But what is due to anybody? Capitalism, socialism, social democracy, social liberalism, no-liberalsim, decent nationalism?

\section{Conclusion: Towards Double Rule of Law}

The recent surge in domestic political violence and the increased resort to brinkmanship in interstate relationships do not bode well at a time when countries ought to start concentrating upon their COP21 Agreement and what national government, IGO:s and NGO:s have committed their countries to do during this century, viz. save Planet Earth by massive decarbonisaion. Russia has taken Crimea but will never be able to hold on to Eastern Ukraine. China is testing the resolve of ASEAN and Pacific Powers by militarizing tiny islands that will drown with ocean rise (very easy to bomb) and North Korea continues its stupidities that may release nuclear confrontation. Domestically, Islam has been revolutionised theologically or philosophically, turning the single largest civilisation in the world into a recruitment base for Koranic terrorism with a scope and range that overshadows ancient terrorist practices with Robespierre, Napoleon and Lenin. Maududi, Qutb and Faraj will become as famous as Hayek, von Mises and Freedman in setting the political tone of a century, the latter in the 20th century demolishing socialist planing, and the former in globalising radical Islam.

There is one remedy only: rule of law. It is not a capitalist notion, but suits both domestic and international institutionalisation of universal rights, procedures, and limitations on state power. Turkey has never had a rule of law legacy, which explains Erdogan's (MB) repression of Kemalist secularism. By not respecting the most institutionalised form of international rule of law, the US (read Bush, Rumsfeld and Wolfowitz) throws the Middle East into a calamity with few precedents in human history. The sufferings in the destruction of the Syrian nation are beyond empathy, resulting from the breaking and neglecting a spontaneous order. Peace is only possible in the 21 st century on the basis of global rule of law, i.e. respect for public international law, like for instance the Haag decision of South China Sea. Of course, rule of law or normativity is to be taken seriously, even if it is only man made institutions with subjective validity. The push for global democracy is not the basis for civilisation co-ordination whose task only double rule of law can accomplish.

The slow but seemingly unstoppable reintroduction of authoritarian practices in China and Russia, the universal spread of "capitalisme sauvage" (bonus culture in advanced countries, embezzlement and patronage in Third World countries) at the expense of institutionalised capitalism (Mises' market economy), the return of nationalism in Europe and all phenomena detract mankind from the lethal threat of climate change-Human history has only an "end", if it is an evolutionary outcome, like climate change. What could bring the world together is not Western values, but universal ones like first and foremost rule of law, in its double Kantian meanings. Countries need

to concentrate their efforts upon climate change policy-making and environmental 
management, both domestically and internationally. Russia and China play brinkmanship games that could derail the entire COP21 process. For the third time, Russia is deeply involved in Moslem conflicts with the attending costs, economically and in human lives. Had Russia developed into a stable rule of law country after 1917, Russian people would have been spared much suffering, not only yesterday but also now. As a matter of fact, Nobel's brother imagined another future for Russia in his capitalist endeavours in Baku.

The new Islam, based upon complete islamisation, a new caliphate and total jihad, refuses the rule of law fro Moslems. It breaks their civilisation, spreading terrible political violence (Gabriel, 2002; Gambetta \& Hertog, 2007; Gold, 2003; Hafez, 2003; Balta, 1991; Bani Sadr, 1989; Baram, 2005; Barber, 1996; Bergen, 2002; Bergensen, 2007, Rahman, 1982; Rahman, 1987; Miller \& Kenedi, 2002). Actually, global rule of law everywhere-domestically and externally-also in the Koranic world-would trump democracy, which is culture bound (Scholte, 2011; Held, 1995; Crawford \& Koskenniemi, 2012). Rule of law is universally applicable-also in Syria, Iraq and elsewhere. It is the greatest idea in political thought (Bickerton, Cunliffe, \& Gourevitch, 2006).

\section{References}

Abadie, A. (2004). Poverty, Political Freedom, and the Roots of Terrorism. Faculty Research Working Papers Series, Cambridge, MA: Harvard University, John F. Kennedy School of Government.

Abu-Rabi', I. (1996). Intellectual Origins of Islamic Resurgence on the Modern Arab World. Albany, NY: State University of New York Press.

Ali, T. (2002). The Clash of Fundamentalisms: Crusades, Jihads and Modernity. London: Verso; In French (2002) Le Choc des Intégrismes. Paris: Textuel.

Al-Najjar Fatiha Dazi-Héni, G. (2006). Monarchies et sociétés d'Arabie: Le temps des confrontations. Paris: Les Presses de Sciences Po.

Al-Zawahiri, A. (1991). The Bitter Harvest (Internet Edition).

Ashmawy, M. S. (1994). Islamic Society in Practice. Barcelona: UPF.

Ayubi, N. N. (2003). Political Islam. London: Routledge.

Azmeh, A. A. (1996). Islam and Modernities. London: Verso.

Babès, L., \& Oubrou, T. (2002). Loi d'Allah, loi des hommes. Paris: Albin Michel.

Bachar, S., Bar, S., Machtiger, R., \& Minzili, Y. (2006). Establishment Ulama and Radicalism in Egypt, Saudi Arabia, and Jordan. Center on Islam, Democracy and the Future of Muslim World (Series No. 1, Paper No. 4). Hudson Institute.

Badawi, A. (1968). La transmission de la philosophie grecque au monde arabe. Paris: Vrin.

Badawi, A. (1972). Histoire de la philosophie en islam (2 volumes). Paris: Vrin.

Baderin, M. A. (2003). International Human Rights and Islamic Law. Oxford: Oxford University Press.

Badie, B. (1986). Les deux Etats: Pouvoir et société en Occident et en terre d'islam. Paris: Fayard. Balta, P. (1991). L'islam dans le monde. Paris: Le monde de l'édition.

Bani Sadr, A. H. (1989). Le Coran et les droits de l'homme. Paris: Maisonneuve et Larose. 
Baram, A. (2005). Who Are the Insurgents? Sunni Arab Rebels in Iraq. Special Report 160, United States Institute of Peace. www.usip.org

Barber, B. D. (1996). Djihad versus McWorld. Paris: Desclée de Brouwer.

Barry, B. (1995). Justice as Impartiality. Oxford: OUP.

Barry, B. (2005). Why Social Justice Matters. Cambridge: Polity Press.

Bergen, P. (2002). The Holy War, Inc.: Inside the Secret World of Osama Bin Laden. Phoenix, AZ: Mass Market.

Bergensen, A. (2007). The Sayyid Qutb Reader. London: Routledge.

Besson, S., \& Tasioulas. J. (Eds.) (2010). The Philosophy of International Law. Oxford: Oxford University Press.

Bickerton, C., Cunliffe, P., \& Gourevitch, A. (Eds.) (2006). Politics without Sovereignty: A Critique of Contemporary International Relations. London: Routledge.

Burgat, F. (2008). Islamism in the Shadow of al-Qaeda. London: I.B. Tauris.

Caney, S. (2006). Justice beyond Borders. A Global Political Theory. Oxford: Oxford University Press.

Choudhury, M. A. (2003). The Islamic World-System. London: Routledge.

Corbin, J. (2002). Al-Qaeda: In Search of the Terror Network that Threatens the World. New York: Thunder's Mouth Press/Nation Books.

Crawford, J., \& Koskenniemi, M. (Eds.) (2012). The Cambridge Companion to International Law. Cambridge: Cambridge University Press. http://dx.doi.org/10.1017/CCO9781139035651

Crone, P. (1999). Weber, Islamic Law, and the Rise of Capitalism. In T. E. Huff, \& W. Schluchter (Eds.), Max Weber and Islam (pp. 247-272). New Brunswick, NY: Transaction.

Dobner, P., \& Loughlin, M. (2012). The Twilight of Constitutionalism? Oxford: Oxford University Press.

Dunoff, J. L., \& Trachtman, P. (Eds.) (2009). Ruling the World? Constitutionalism, International Law, and Global Governance. Cambridge: Cambridge University Press.

Dworkin, R. (1986). Law’s Empire. Cambridge, MA: Harvard University Press.

Dworkin, R. (2000). Sovereign Virtue: The Theory and Practice of Equality. Cambridge, MA: Harvard University Press.

Eliasson, S., Mindus, P., \& Turner, S. (Eds.) (2012). Axel Haegerstoem and Modern Social Thought. Oxford: Bardwell Press.

Fukuyama, F. (1992). The End of History and the Lat Man. New York: Free Press.

Gabriel, M. A. (2002). Islam and Terrorism. Lake Mary, FL: Charisma House.

Gambetta, D., \& Hertog, S. (2007). Engineers of Jihad. Sociological Working Papers, No. 2007-10, Oxford: University of Oxford.

Gold, D. (2003). Hatred's Kingdom: How Saudi Arabia Supports New Global Terrorism. Washington DC: Regnery.

Goldsmith, J. L., \& Posner, E. A. (1995). The Limits of International Law. Oxford: Oxford University Press.

Haegerstroem, A. (1953). Inquiries into the Nature of Morals and Law. Stockholm: Almqvist \& Wicksell.

Hafez, M. M. (2003). Why Muslims Rebel: Repression and Resistance in the Islamic World. Boulder, CO: Lynne Rienner.

Hardie, J. B. (1970). Social Justice in Islam. Translation of S. Qutb. New York: Octagon Books. 
Hare, R. (1972). Essays on the Moral Concepts. Oxford: Clarendon Press. http://dx.doi.org/10.1007/978-1-349-01278-7

Hashim, A. (2014). From Al-Qaeda Affiliate to the Rise of the Islamic Caliphate: The Evolution of the Islamic state of Iraq and Syria (ISIS). Singapore: S. Rajaratnam School of International Studies (RSIS), Nanyang Technological University (NTU).

Held, D. (1995). Democracy and the Global Order: From the Modern State to Cosmopolitan Governance. Stanford, CA: Stanford University Press.

Huff, T. E., \& Schluchter, W. (Eds.) (1999). Max Weber and Islam. London: Transaction.

Juergensmeyer, M. (2000). Terror in the Mind of God: The Global Rise of Religious Violence. Berkeley, CA: University of California Press.

Kant, I. (1991). Political Writings (Ed. H. Reiss). Cambridge: Cambridge University Press.

Kelsen, H. (1911). Hauptprobleme der Staatrechtslehre. Tubingen: Mohr.

Keohane, R. (2005). After Hegemony. Princeton, NJ: Princeton University Press.

Kepel, G. (2000). Jihad. Paris: Gallimard; Trans. (2003) Jihad: The Trail of Political Islam. London: I.B. Tauris.

Kepel, G. (2004). The War for Muslim Minds: Islam and the West. Cambridge, MA: The Belknap Press.

Kepel, G. (2005). The Roots of Radical Islam. London: Saqi Books.

Kepel, G. (2008). Beyond Terror and Martyrdom: The Future of the Middle East. Cambridge, MA: Harvard University Press.

Klabbers, J., Peters, A., \& Ulfstein, G. (2011). The Constitutionalization of International Law. Oxford: Oxford University Press.

Krasner, S. D. (1999). Sovereignty: Organized Hypocrisy. Princeton, NJ: Princeton University Press. http://dx.doi.org/10.1515/9781400823260

Krasner, S. D. (Ed.) (1983). International Regimes. Ithaca, NY: Cornell University Press.

Krisch, N. (2011). Beyond Constitutionalism: The Pluralist Structure of Postnational Law. Oxford: Oxford University Press.

Manners, I. (2002). Normative Power Europe: A Contradiction in Terms? Journal of Common Market Studies, 40, 235-258. http://dx.doi.org/10.1111/1468-5965.00353

Metcalf, B. (1982). Islamic Revival in British India: Deoband, 1860-1900. Princeton, NJ: Princeton University Press. http://dx.doi.org/10.1515/9781400856107

Metcalf, B. (1999). Weber and Islamic Reform. In T. E. Huff, \& W. Schluchter (Eds.), Max Weber and Islam (pp. 217-230). London: Transaction.

Miller, J., \& Kenedi, A. (Eds.) (2002). Inside Islam: The Faith, the People and the Conflicts of the World's Fastest-Growing Religion. New York: Avalon.

Milton-Edwards, B., \& Hinchcliffe, P. (2001). Jordan: A Heshemite Legacy. London: Routledge.

Moaddel, M., \& Talattof, K. (Eds.) (2000). Contemporary Debates in Islam: An Anthology of Modernist and Fundamentalist Thought. Basingstoke: Palgrave Macmillan.

Moghadem, A. (2007). Mayhem, Myths, and Martyrdom: The Shi'a Conception of Jihad. Terrorism and Political Violence, 19, 125-143. http://dx.doi.org/10.1080/09546550601079656

Mussallam, A. A. (2005). From Secularism to Jihad: Sayyd Qutb and the Foundations of Radical Islamism. New York: Praeger.

Pogge, T. (Ed.) (2002). Global Justice. Oxford: Wiley-Blackwell.

Popper, K. R. (1934, 2002). The Logic of Scientific Discovery. London: Routledge. 
Posner, E. (2009). The Perils of Global Legalism. Chicago, IL: University of Chicago Press. http://dx.doi.org/10.7208/chicago/9780226675923.001.0001

Posner, R. (1993). The Problems of Jurisprudence. Cambridge, MA: Harvard University Press.

Qureshi, I. H. (1980). Milestones. Beirut: The Holy Koran Publishing House.

Qutb, S. (1990). Milestones. Indianapolis, IN: American Trust Publications.

Qutb, S. (2000). Social Justice in Islam (Trans. J. B. Hardie). New York: Octagon Books.

Qutb, S. (2005). Basic Principles of Islamic Worldview. North Haledon, NJ: Islamic Publications International.

Rahbar, D. (1956). Sir Sayyid Ahmed Khan’s Principles of Exegesis (Trans. from “Tahrîr fî usûls al-tafsîr). Muslim World, 46, 104-112. http://dx.doi.org/10.1111/j.1478-1913.1956.tb02915.x

Rahman, F. (1982). Islam and Modernity. Transformation of an Intellectual Tradition. Chicago, IL: The University of Chicago Press.

Rahman, M. (Ed.) (1987). Muslim World. Lanham, MD: University Press of America.

Rawls, J. (1971). A Theory of Justice. Cambridge: Harvard University Press.

Rawls, J. (2001). The Law of Peoples. Cambridge, MA: Harvard University Press.

Raz, J. (2009). The Authority of Law (2nd ed.). Oxford: Oxford University Press.

Robinson, F. (1999). Secularisation, Weber and Islam. In T. E. Huff, \& W. Schluchter (Eds.), Max Weber and Islam (pp. 231-245). New Brunswick, NY: Transaction.

Rodinson, M. (1993). L'Islam politique et croyance. Paris: Fayard.

Roy, O. (1994). The Failure of Political Islam. Cambridge, MA: Harvard University Press.

Roy, O. (2000). The New Central Asia: Creation of Nations. London: I.B. Tauris.

Roy, O. (2004). Globalised Islam: The Search for a New Ummah. London: Hurst.

Roy, O. (2007). Secularism Confronts Islam. New York: Columbia University Press.

Roy, O. (2008). The Politics of Chaos in the Middle East. London: Hurst.

Schluchter, W. (1987). Max Webers Sicht des Islams. Interpretation und Kritik. Frankfurt: Suhrkamp.

Schluchter, W. (1989). Rationalism, Religion and Domination. Berkeley, CA: University of California Press.

Schmitt, C. (1928, 2002). Verfassungslehre. Berlin: Duncker und Humblot.

Scholte, J. A. (Ed.) (2011). Building Global Democracy. Cambridge: Cambridge University Press. http://dx.doi.org/10.1017/CBO9780511921476

Sivan, E. (1995). Mythes politiques arabes. Paris: Fayard/Esprit de la cité.

Sivan, E. (1985). Radical Islam. Medieval Theology and Modern Politics. New Haven, CT: Yale University Press.

Sivan, E. (1997). Constraints \& Opportunities in the Arab World. The Journal of Democracy, 8 , 102-113. http://dx.doi.org/10.1353/jod.1997.0032

Teitel, R. G. (2011). Humanity’s Law. Oxford: Oxford University Press. http://dx.doi.org/10.1093/acprof:oso/9780195370911.001.0001

Weber, M. (1978). Economy and Society, Volumes I-II. Berkeley, CA: University of California Press.

Young, O. (1989). International Cooperation. Ithaca, NY: Cornell University Press. 
Submit or recommend next manuscript to SCIRP and we will provide best service for you:

Accepting pre-submission inquiries through Email, Facebook, LinkedIn, Twitter, etc. A wide selection of journals (inclusive of 9 subjects, more than 200 journals)

Providing 24-hour high-quality service

User-friendly online submission system

Fair and swift peer-review system

Efficient typesetting and proofreading procedure

Display of the result of downloads and visits, as well as the number of cited articles

Maximum dissemination of your research work

Submit your manuscript at: http://papersubmission.scirp.org/

Or contact ojps@scirp.org 